SCIENCE OF ENGINEERING MATERIALS 
Science of Engineering Materials

Volume 1 Structure of Matter

Volume 2 Materials

Volume 3 Engineering Properties 


\section{Science of Engineering Materials}

Volume 2

Materials

Manas Chanda

Indian Institute of Science, Bangalore

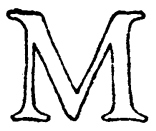


(C) Manas Chanda 1979

All rights reserved. No part of this publication may be reproduced or transmitted, in any form or by any means, without permission.

First published in India 1979 by

Macmillan India Ltd

First published in Great Britain 1981 by

THE MACMILLAN PRESS LTD

London and Basingstoke

Companies and representatives

throughout the world

Additional material to this book can be downloaded from http://extras.springer.com

ISBN 978-0-333-31816-4

ISBN 978-1-349-06053-5 (eBook)

DOI 10.1007/978-1-349-06053-5

The paperback edition of the book is sold subject to the condition that it shall not, by way of trade or otherwise, be lent, resold, hired out, or otherwise circulated without the publisher's prior consent in any form of binding or cover other than that in which it is published and without a similar condition including this condition being imposed on the subsequent purchaser. 
To the loving memory of

The Late Smt. Nityabala Chaudhuri 


\section{Foreword}

Materials science is an interdisciplinary subject of great importance. It is increasingly being recognised that a course in materials science should form an essential part of engineering science curricula in universities. This is because of the rapid progress being made in the development of sophisticated tailor-made materials of desired properties and specifications to suit specific needs. The subject is, therefore, not only of relevance to engineering but also to physical sciences, medical science, and other disciplines. Thus, modern medical practice makes use of new bio-materials while modern solid state chemistry is concerned with the synthesis of novel kinds of compounds. An introduction to materials science will undoubtedly enable students, teachers and professionals to appreciate the problems related to materials in the modern world.

This book by Dr. Manas Chanda attempts to present an introduction to engineering materials science, which I am sure will be found useful by the scientific and educational community. Dr. Chanda has taken pains to work out examples and problems which will be useful to students. I recommend the book to students and teachers of materials science.

\section{Bangalore}

22 February 1979 


\section{Preface}

The properties or behaviour of every kind of engineering material depend upon its internal structure, and the hierarchy of such structures ranges from the atomic and molecular level through the crystalline structure to microstructures and macrostructures. Volume 1 of this book dealt, in its five chapters, with the structure of atoms and molecules, the characteristics and molecular make-up of the different states of matter, and the structure of crystalline and amorphous solid phases. The present volume, composed of six chapters, presents an organised study of multiphase systems, dealing with microstructures, macrostructures, and behavioural characteristics of the main classes of engineering materials.

General phase equilibrium relationships, phase changes and phase or grain ckaracteristics are dealt with in Chapter 1, which also presents a concerted treatment of the major processes that control the grain characteristics, such as recrystallisation, grain growth and sintering, with examples drawn from both metallic and nonmetallic systems. Chapter 2 is devoted to a detailed study of phases and phase transformations in iron-carbon systems, in recognition of their great importance in engineering. The next four chapters are concerned with the four main groups of engineering materials-metals and alloys, plastics, ceramics, and composites. The discussion in these chapters emphasises how the internal make-up and structure can be designed or considerably modified by various manufacturing processes and treatments to impart completely different characteristics to the material. Ferrous and non-ferrous alloys are discussed from this angle in Chapter 3, 
followed by polymeric materials in Chapter 4. Polymeric materials present a striking example of the fact that we are no longer forced to accept the atomic and molecular arrangements produced by nature, but we can modify and tailor them to produce desired properties for particular applications. Thus, by varying the molecular make-up of polymers, by varying the length of the molecular chain and its characteristics such as its stiffness and symmetry or by controlling the degree and type of cross-linking, we can produce a wide range of materials for different applications. The discussion in Chapter 4 is oriented to emphasise this viewpoint.

Over the last few decades, the ancient art of ceramics has been transformed into the science of materials engineering, helped by an understanding of the relation between structure and properties that permits better control of chemical composition and microstructure, and designing new materials for technology. A study of ceramic materials from this viewpoint is presented in Chapter 5. The next chapter deals with composite materials, highlighting the factors, such as the nature of the constituents and the relations and interactions between the constituents, which determine the properties and behaviour of composites.

At the end of each chapter, there are problems to enhance the reader's understanding of the concepts discussed in the text. Original references and an important bibliography have been cited at the end of each chapter which should help the readers in their attempts to widen their horizon and deepen their understanding of the subject through further studies.

CGS units have been used throughout the text. However, in view of the growing acceptance of the international (SI) metric system, the book provides a table of basic, derived and supplementary SI units, as well as conversion factors to facilitate conversion to SI units. Besides, in many places in the text, SI equivalents have been given to afford familiarity with this system in relation to the CGS system. This should assist the reader in gradual transition from the present use of mixed units to the SI units.

In writting a book of this kind, one accumulates indebtedness to a wide range of people, not the least to the authors of earlier publications in the field. I particularly wish to acknowledge the help given by Professors I. A. Aksay and J. A. Pask of the 
Department of Materials Science and Engineering, University of California, Berkeley, American Society for Metals, Ohio and the American Association for the Advancement of Science, Washington. My farulty colleagues, innumerable students and academic associates in other universities and colleges, have provided much welcome stimulation and direct help. I am much indebted to Professor C. N.R. Rao for writing a foreword to the book. I wish to thank Messrs. M. N. Chandrashekara, P. Raghavendrachar and C. C. Lakshmanan, who performed the task of proof-reading during my visit abroad. The grant of subsidy from the National Book Trust of India for the publication of the book is gratefully acknowledged.

Bangalore

February, 1979

Manas Chanda 


\section{Basic Units and Conversion Factors}

\begin{tabular}{|c|c|c|c|}
\hline Quantity & English & $C G S$ & $S I(M K S)$ \\
\hline Length & $1 \mathrm{ft}=12 \mathrm{in}$ & $30.48 \mathrm{~cm}$ & $0.3048 \mathrm{~m}$ \\
\hline Volume & $1 \mathrm{ft}^{3}=7.481 \mathrm{gal}$ & $28,320 \mathrm{~cm}^{3}=28.32$ litres & s $0.0283 \mathrm{~m}^{3}$ \\
\hline Mass & $1 \mathrm{lbm}$ & $453.6 \mathrm{~g}$ & $0.4536 \mathrm{~kg}$ \\
\hline Density & $1 \mathrm{lbm} / \mathrm{ft}^{3}$ & $0.01602 \mathrm{~g} / \mathrm{cm}^{3}$ & $16.02 \mathrm{~kg} / \mathrm{m}^{3}$ \\
\hline Force & $1 \mathrm{lbf}$ & $4.448 \times 10^{5}$ dyn & 4.448 Newton(N) \\
\hline \multirow[t]{2}{*}{ Pressure } & 1 bar & $10^{6} \mathrm{dyn} / \mathrm{cm}^{2}$ & $10^{5} \mathrm{~N} / \mathrm{m}^{2}$ \\
\hline & 1 psi & $6.895 \times 10^{4} \mathrm{dyn} / \mathrm{cm}^{2}$ & $\begin{array}{r}6.895 \times 10^{3} \mathrm{~N} / \mathrm{m}^{2} \\
=6.895 \times 10^{3} \\
\quad \text { Pascal }(\mathrm{Pa})\end{array}$ \\
\hline Energy & 1 Btu (mean) & $252.03 \mathrm{cal}$ & $1.056 \times 10^{3}$ Joule $(\mathrm{J})$ \\
\hline Work & $1 \mathrm{ft} . \mathrm{lbf}$ & $1.356 \times 10^{7} \mathrm{erg}$ & $1.356 \mathrm{~J}$ \\
\hline Power & $\begin{array}{l}1 \mathrm{Btu} / \mathrm{sec} \\
=778.3 \mathrm{ft} . \mathrm{lbf} / \mathrm{sec}\end{array}$ & $1.056 \times 1010 \mathrm{erg} / \mathrm{sec}$ & 1.056 Watt (W) \\
\hline $\begin{array}{l}\text { Surface } \\
\text { tension }\end{array}$ & $6.854 \times 10^{-6} \mathrm{lbf} / \mathrm{ft}$ & $1 \mathrm{dyn} / \mathrm{cm}$ & $10^{-3} \mathrm{~N} / \mathrm{m}$ \\
\hline Viscosity & $0.0672 \mathrm{lbm} / \mathrm{ft} . \mathrm{sec}$ & 1 poise $\left(\right.$ dyn. $\left.\mathrm{sec} / \mathrm{cm}^{2}\right)$ & 0.1 N. $\sec / \mathrm{rn}^{2}$ \\
\hline $\begin{array}{l}\text { Viscosity, } \\
\text { kinematic }\end{array}$ & & 1 Stoke $\left(\mathrm{cm}^{2} / \mathrm{sec}\right)$ & $10^{-4} \mathrm{~m}^{2} / \mathrm{sec}$ \\
\hline
\end{tabular}


Additional Conver,ion Units

$$
\begin{array}{rlrl}
1 \stackrel{\circ}{\mathrm{A}}=10^{-8} \mathrm{~cm}=10^{-10} \mathrm{~m} & 1 \mathrm{kgf} / \mathrm{mm}^{2}=100 \mathrm{kgf} / \mathrm{cm}^{2} \\
1 \mu=10^{-4} \mathrm{~cm}=10^{-6} \mathrm{~m} & & =9.807 \times 10^{6} \mathrm{~N} / \mathrm{m}^{2} \\
1 \mathrm{~atm} & =76 \mathrm{~cm} \mathrm{Hg}\left(\text { at } 0^{\circ} \mathrm{C}\right) & 1 \mathrm{HP} & =550 \mathrm{ft} . \mathrm{lbf} / \mathrm{sec}=2545 \mathrm{Btu} / \mathrm{hr} \\
& =14.696 \mathrm{psi} & & =746 \mathrm{~W} \\
1 \mathrm{ev} & =1.602 \times 10^{-12} \mathrm{erg} & \mathrm{t}^{\circ} \mathrm{C}=(1.8 \mathrm{t}+32)^{\circ} \mathrm{F} \\
1 \mathrm{cal} & =4.19 \mathrm{~J} & \mathrm{t}^{\circ} \mathrm{F}=\frac{5}{8}(\mathrm{t}-32)^{\circ} \mathrm{C}
\end{array}
$$

$1 \mathrm{ev} / \mathrm{molecule}=23,061 \mathrm{cal} / \mathrm{mole}$ 


\section{Contents}

Foreword vii

Preface ix

Basic Units and Conversion Factors xiii

CHAPTER 1: PHASE EQUILIBRIA, PHASE CHANGES AND PHASE CHARACTERISTICS 1

1.1 Introduction 1

1.2 The Phase Rule and Definitions 1

1.3 Phase Equilibria of One-and Two-component Systems 4 One-component systems. Two-component systems

1.4 Classification of Alloys 7

Single-phase alloys. Multi-phase alloys

1.5 Equilibrium Phase Diagrams of Binary Alloy Systems

Construction of equilibrium diagrams. Basic types of binary equilibrium diagrams. Properties of eutectic system alloys. Age-hardening or precipitation hardening.

1.6 Ternary Phase Equilibrium Diagram 30

1.7 Phase Changes 34

Phase transformation processes

1.8 Grain Microstructures

Techniques of studying microstructures. Microstructural characteristics. Processes controlling microstructures 
Notes $\quad 61$

References 61

Further Reading $\quad 62$

Problems $\quad 63$

CHAPTER 2: PHASES AND PHASE TRANSFORMATION IN IRON-CARBON SYSTEM

2.1 Introduction 65

2.2 Iron-Iron Carbide Equilibrium Diagram 65

2.3 Time-Temperature-Transformation (T-T-T) Diagram 71 Isothermal formation of bainite. Formation of martensite. Factors affecting the I-T diagram. Use of $\mathrm{T}-\mathrm{T}-\mathrm{T}$ diagram

2.4 Continuous-Cooling-Transformation (C-C-T) Diagram 81

2.5 Heat Treatment of Carbon Steels

Austenitising. Full annealing. Stress-relief annealing and process annealing. Normalising. Spheroidising. Hardening. Tempering. Austempering. Martempering. Ausforming

2.6 Hardenability

Jominy test. The significance of hardenability

Notes

References

Further Reading

Problems

3.1 Introduction

Effect of alloying elements. Manganese steels. Nickel steels. Chromium steels. Nickel-chromium steels. Molybdenum steels. Vanadium steels. Tungsten 
steels. Silicon steels. Stainless steels. Austenitic stainless steels

3.3 Tool Steels

3.4 Cast Irons

Gray cast iron. Nodular cast iron. White cast iron. Malleable cast iron. Alloy cast iron

3.5 Wrought Iron

3.6 Non-ferrous Metals and Alloys

Copper and copper alloys. Nickel and nickel alloys. Aluminium, magnesium and their alloys. Magnesium and its alloys. Lead and tin. Zinc and zinc alloys

3.7 Metals for High-temperature Service

Notes

References

Further Reading

Problems

\section{CHAPTER 4: POLYMERIC MATERIALS}

4.1 Introduction

4.2 Polymer Molecules

4.3 Molecular Lengths of Polymers

4.4 Molecular Weight of Polymers

Number-average molecular weight $\left(\boldsymbol{M}_{n}\right)$. Weightaverage molecular weight $\left(\boldsymbol{M}_{w}\right)$. Viscosity-average molecular weight $\left(\widehat{M}_{v}\right)$. Polydispersity index

4.5 Definition of 'Resin' and 'Plastic'

4.6 Polymerization Processes

Step polymerization. Chain or addition polymerization. Copolymerization

4.7 Structural Shape of Polymer Molecules

4.8 Cross-linking of Polymer Chains

4.9 Stereoisomerism of Linear Polymers 
4.10 Crystalline and Amorphous Behaviour of Polymers

Determinants of polymer crystallinity

4.11 Thermal Transitions of Polymers

171

4.12 Designing Polymer Structure for Improved Properties

174

4.13 Composite Materials Incorporating Polymers

Notes

178

References

179

Further Reading

180

Problems

181

CHAPTER 5: CERAMIC MATERIALS

184

5.1 Introduction

184

5.2 Structure of Silicates

Discrete anions. Extended anions. Three-dimensional networks

5.3 Refractories

High-grade refractories. Applications of refractories. Fireclay refractories. Mullite refractories. Silica refractories. Magnesite refractories. Chrome and chrome-magnesite refractories. Carbon and graphite refractories. Carbide and nitride refractories. Pure oxide refractories. Heat-insulating refractories

5.4 Glasses

The structure of glass. Glass formation in oxides. General properties of glass. Types of glass. Glass processing. Glass in industry and engineering

5.5 Glass-like Coatings

5.6 Ceramic Coatings

5.7 Cement and Concrete

Portland cement. Aluminous cements. Concrete Notes 
Further Reading

6.1 Introduction

6.2 Combination-dependent Properties

Contributive properties. Interactive properties

6.3 Strengthening Mechanisms

Dispersion-strengthened composites. Particulatestrengthened composites. Fibre-reinforced composites

6.4 Factors in Composite Preparation

6.5 Fibre Composites

Advanced fibre composites. Whisker composites

6.6 Particle Composites

References

Further Reading

Problems

Index 